\title{
A new Rovno amber termite genus (Isoptera, Rhinotermitidae) from Styr river basin
}

\author{
Evgeny E. Perkovsky and André Nel
}

\begin{abstract}
Lukotermes milescaput gen. et sp. nov. is described on the basis of a dealate specimen from the Eocene amber of Vladimirets district of Rovno region (Ukraine). We provisionally attribute it to the family Rhinotermitidae, subfamily Heterotermitinae for its head shape. It is remarkable for its elongate head capsule with lateral sides parallel and its tibial spur formula 2:2:2. This last character is quite infrequent in this family, also present in the closely related family Serritermitidae, questioning its phylogenetic relationships. This point will be clarified only after the discovery of other specimens showing the wing venation and the mandibular dentition. It is also a very small termite, smallest fossil rhinotermitid, and the second smallest Paleogene termite after the Ypresian genus Nanotermes Engel and Grimaldi, 2011. It was supposed that initial weight of parents was more crucial in mesothermal climates with low seasonality of Priabonian European amber forests than in tropical climate of Ypresian Cambay forest. It could be the reason why miniaturization is very strong in Cambay termites and hardly seen in Priabonian ambers, rather than taphonomic biases.
\end{abstract}

Evgeny E. Perkovsky. Schmalhausen Institute of Zoology, National Academy of Sciences of Ukraine, Kiev, 01030 Ukraine and 2 A.A. Borissiak Paleontological Institute, Russian Academy of Sciences, Profsoyuznaya Str. 123, Moscow,117868 Russia. perkovsk@gmail.com; https://orcid.org/0000-0002-79594379

André Nel. Institut de Systématique, Évolution, Biodiversité (ISYEB) Muséum national d'Histoire naturelle, CNRS, Sorbonne Université, EPHE, Université des Antilles, CP50, 57 rue Cuvier 75005 Paris, France. anel@mnhn.fr; https://orcid.org/0000-0002-4241-7651

Keywords: Blattodea; Eocene; new genus; new species; Heterotermitinae

Submission: 8 September 2020. Acceptance: 28 January 2021.

https://zoobank.org:pub:2CC22870-292E-46D0-9E4C-2BFC056329AE

Perkovsky, Evgeny E., and Nel, André. 2021. A new Rovno amber termite genus (Isoptera, Rhinotermitidae) from Styr river basin. Palaeontologia Electronica, 24(1):a05. https://doi.org/10.26879/1127

palaeo-electronica.org/content/2021/3299-new-termite-from-rovno-amber

Copyright: February 2021 Paleontological Society.

This is an open access article distributed under the terms of Attribution-NonCommercial-ShareAlike 4.0 International (CC BY-NC-SA 4.0), which permits users to copy and redistribute the material in any medium or format, provided it is not used for commercial purposes and the original author and source are credited, with indications if any changes are made. creativecommons.org/licenses/by-nc-sa/4.0/ 


\section{INTRODUCTION}

Ukrainian Rovno amber (Priabonian stage, 33.9-37.8 Ma) is the southern coeval of notorious Baltic amber (Perkovsky et al., 2010). In the most studied order, Hymenoptera, $50 \%$ of recorded Rovno species are unknown from Baltic amber (Perkovsky, 2018; Simutnik and Perkovsky, 2020; Radchenko and Perkovsky, 2020). Nearly all Rovno amber material, scientifically studied before 2015, was mined in Klesov (Sarny district), but since 2015 most inclusions were found in the basins of Styr, Veselukha and Horyn (Vladimirets, Zarechnoje, and Dubrovitsa districts). Many taxa are unknown from Klesov, but recorded from Baltic amber, as well as first Rovno records of some Baltic amber species were reported from this area (Perkovsky and Olmi, 2018; Radchenko and Perkovsky, 2018; Perkovsky and Makarkin, 2019, 2020; Legalov et al., 2019; Martynova et al., 2019; Makarkin and Perkovsky, 2020; Mamontov et al., 2020; Lyubarsky and Perkovsky, 2020a; Radchenko and Khomich, 2020; Perkovsky et al., 2020; etc.).

Scientific study of Rovno amber inclusions started from Electrotermes von Rosen, 1913 (Kalotermitidae) syninclusions (Perkovsky, 2000), but termites of Rovno amber were not specially studied until 2020 (Perkovsky et al., 2010; Perkovsky and Vasilenko, 2020), while Baltic amber termites are well known with many described species (Engel et al., 2007; Engel, 2008; Krishna et al., 2013). Among these, the Rhinotermitidae are among the most frequently encountered, mainly by alate specimens of two species of Reticulitermes Holmgren, 1913. The extant representatives of this family are present under a wide variety of climates. Even if their maximal diversity is under warm tropical regions, the genus Reticulitermes is well present and diverse in the southern parts of the Holarctic empire. The fossil record of this family is currently reduced to the Cenozoic of North and Central America and Eurasia (including India) (see Fossilworks database). After Jouault et al. (personal commun., 2020), the family should originate in the Cretaceous. Here we describe a new rhinotermitid genus and species on the basis of a dealate adult that was glued in the fresh resin just after its mating swarm. This fossil is among the smallest known fossil or extant adult termites.

\section{MATERIAL AND METHODS}

The localities and composition of the Rovno amber fauna were recently characterized in a series of reviews by Perkovsky et al. (2010), Jałoszyński and Perkovsky (2016), Perkovsky (2016, 2018), and Martynova et al. (2019). Nearly all studied Rovno amber inclusions from Rovno region were collected from Klesov and the Horyn River Basin (Perkovsky et al., 2010; Perkovsky, 2017) except new collections from the more western basins of the Styr and Stokhod rivers and especially the Veselukha River floodplain between them (Lyubarsky and Perkovsky, 2020b). These new collections (mostly from Voronki and Velyki Telkovichi) revealed a number of new species of beetles, hymenopterans, neuropterans, and snakeflies (Jałoszyński and Perkovsky, 2019; Legalov et al., 2019; Perkovsky and Makarkin, 2019; Perkovsky et al., 2020) as well as some species described from Baltic amber (Simutnik et al., 2020 and references therein). Rovno amber, as many other succinites, is redeposited (Nadein et al., 2016). The amber piece with the holotype was collected between the Voronki Village and Lake Luko (ca. 35 $\mathrm{km}$ to south of Belorussia border) in the former Vladimirets district of Rovno region, together with holotype of the formicine ant Cataglyphoides dlusskyi Radchenko and Khomich, 2020 (Radchenko and Khomich, 2020) and paratype of Parastylotermes nathani Perkovsky, 2020 in Perkovsky and Vasilenko (2020) (other syninclusions listed in Radchenko and Khomich, 2020). The type is deposited in the amber collection of I.I. Schmalhausen Institute of Zoology of National Academy of Sciences of Ukraine (Kiev, SIZK).

The amber piece was $130 \mathrm{~mm}$ long and 74 $\mathrm{mm}$ wide before cutting ( $\mathrm{N}$. Khomich, personal commun.); weight before primary treatment ca 310 g; weight after primary treatment $210 \mathrm{~g}$ (Radchenko and Khomich, 2020), clear but with some gas bubbles and 'waves' around the fossil termite. The piece was cut for Cataglyphoides dlusskyi description with additional cutting to study the syninclusions, resulting in three samples (see Perkovsky et al., 2012). Photographs were taken using a Leica Z16 APO stereomicroscope with a Leica DFC 450 camera and processed with LAS V3.8 software. Morphological terminology follows Krishna et al. (2013).

\section{SYSTEMATIC PALEONTOLOGY}

Order Blattodea Brunner von Wattenwyl, 1882 Infraorder Isoptera Brullé, 1832

Family Rhinotermitidae Light, 1921

?Subfamily Heterotermitinae Froggatt, 1896 Genus Lukotermes gen. nov. 
Type species. Lukotermes milescaput sp. nov. Diagnosis. Imago characters only. Head distinctly longer than wide, with lateral sides parallel; a distinct bump above base of antenna; compound eyes and ocelli small; postclypeus short, without noselike projection; pronotum not very transverse, with an anterior side straight and posterior margin strongly emarginated; forewing scale larger and longer than hind wing one, but only slightly overlapping its base; tibial spur formula 2:2:2; four tarsomeres; cerci two-segmented.

Etymology. Named after Lake Luko situated near the amber outcrop, and termes, common generic stem meaning termite. Neutral.

\section{Lukotermes milescaput sp. nov.}

Figures 1-3

\section{zoobank.org/14A1178E-BAE2-4B8F-8082-9151F9F3FE95}

Type material. Holotype L-122 (well-preserved alate with body, legs, and wing scales preserved, mouthparts hidden by small bubbles), stored at SIZK.

Diagnosis. As for the genus; very small alate, body $3.3 \mathrm{~mm}$ long; 15 antennomeres; antennomeres 3 and 4 very small.

Etymology. Named after the Latin 'miles' for soldier, and 'caput' for head; because of the head similar to that of a soldier.

Age and outcrop. Priabonian, Eocene, Rovno amber, near Voronki Village and Lake Luko, Ukraine.

Description. Imago, female. Body $3.31 \mathrm{~mm}$ long, head length to apex of clypeus $0.80 \mathrm{~mm}$, head width $0.70 \mathrm{~mm}$, head elongate, longer than wide, with lateral sides parallel (Figure 1A-B, D); sparse short setae on head capsule (longest $0.05 \mathrm{~mm}$ long); right antenna with 15 antennomeres (antennomeres 3 and 4 very small); fontanelle weakly visible, situated in anterior part of head capsule with no groove between it and tip of labrum; postclypeus $0.10 \mathrm{~mm}$ long, convex but without nose-like projection; right ocellus more or less visible, 0.10 $\mathrm{mm}$ long; a pronounced bump above base of antenna; compound eye $0.21 \mathrm{~mm}$ long, 0.70 and $0.05 \mathrm{~mm}$ high; distance between middle of eye and posterior side of head/distance between middle of eye and anterior part of head $=1.60$ (eye rather far from anterior part of head); distal labial palpomere much wider than distal maxillary palpomere. Thorax (Figure 1C) $1.0 \mathrm{~mm}$ long, ca. $0.6 \mathrm{~mm}$ wide; pronotum flat, $0.37 \mathrm{~mm}$ long, $0.53 \mathrm{~mm}$ wide, as broad as head with posterior margin strongly emarginate, posterior width along a line passing at median notch 2/3 width along anterior margin; sparse setae pronotum, more numerous on lateral side and pos- terior half; setae are longer than on head, 0.08$0.09 \mathrm{~mm}$ long. Forewing scale $0.43 \mathrm{~mm}$ long, slightly overlapping base of hind wing scale; hind wing scale $0.36 \mathrm{~mm}$ long; forewing $\mathrm{M}$ and $\mathrm{CuA}$ apparently separated in scale; both fore- and hind wing scales covered with setae similar to those on pronotum (longest $0.1 \mathrm{~mm}$ ), directed posteriorly. Four tarsomeres; tibial spur formula 2:2:2 (Figure 2B). Abdomen ca. $1.70 \mathrm{~mm}$ long, $0.70 \mathrm{~mm}$ wide; last sternite broad, 10th (last) tergite, cerci and paraprocts. Cerci two-segmented, with segments of similar lengths (Figure 3); styli and sternal glands not visible.

\section{DISCUSSION}

Following the key of Krishna et al. (2013: 6971), Lukotermes gen. nov. would fall in the group of families Serritermitidae Westwood, 1840 + Rhinotermitidae because of the following characters: antenna with 15 antennomeres; fontanelle present, situated in anterior part of head capsule; forewing scale weakly overlapping base of hind wing scale; pronotum flat, not saddle-shaped; and four tarsomeres. Unfortunately, the shape of the mandible teeth of Lukotermes gen. nov. is unknown, thus the choice between the two options 'each mandible with a long apical tooth, left with 1-2 marginal teeth, right without a subsidiary tooth' (Serritermitidae) vs. 'each mandible with a short apical tooth, left with three marginal teeth, right with a subsidiary tooth' (Rhinotermitidae) cannot be decided (see also Cancello and De Souza, 2005: 4).

In recent molecular phylogenetic analysis (Bucek et al., 2019), Rhinotermitidae appear paraphyletic in respect to Termitidae and Serritermitidae fit inside the Rhinotermitidae. Thus a new morphological phylogenetic analysis is necessary to better evaluate the value of the characters that are currently used to define these two families. This situation renders somewhat uncertain the attribution to the Rhinotermitidae of any fossil genus.

Nevertheless, we shall discriminate our fossil from the described serritermitid or rhinotermitid genera.

The family Serritermitidae only comprises the two extant genera Serritermes Wasmann, 1897 and Glossotermes Emerson, 1950. Both have a tibial spur formula $2: 2: 2$ while it is $3: 2: 2$ in the extant Rhinotermitidae and the Cretaceous subfamily Archeorhinotermitinae (Krishna and Grimaldi, 2003; Maiti, 2006). Only the extant Termitogetoninae Holmgren, 1910 (Termitogeton Desneux, 1904) and the Ypresian genus Zophoter- 


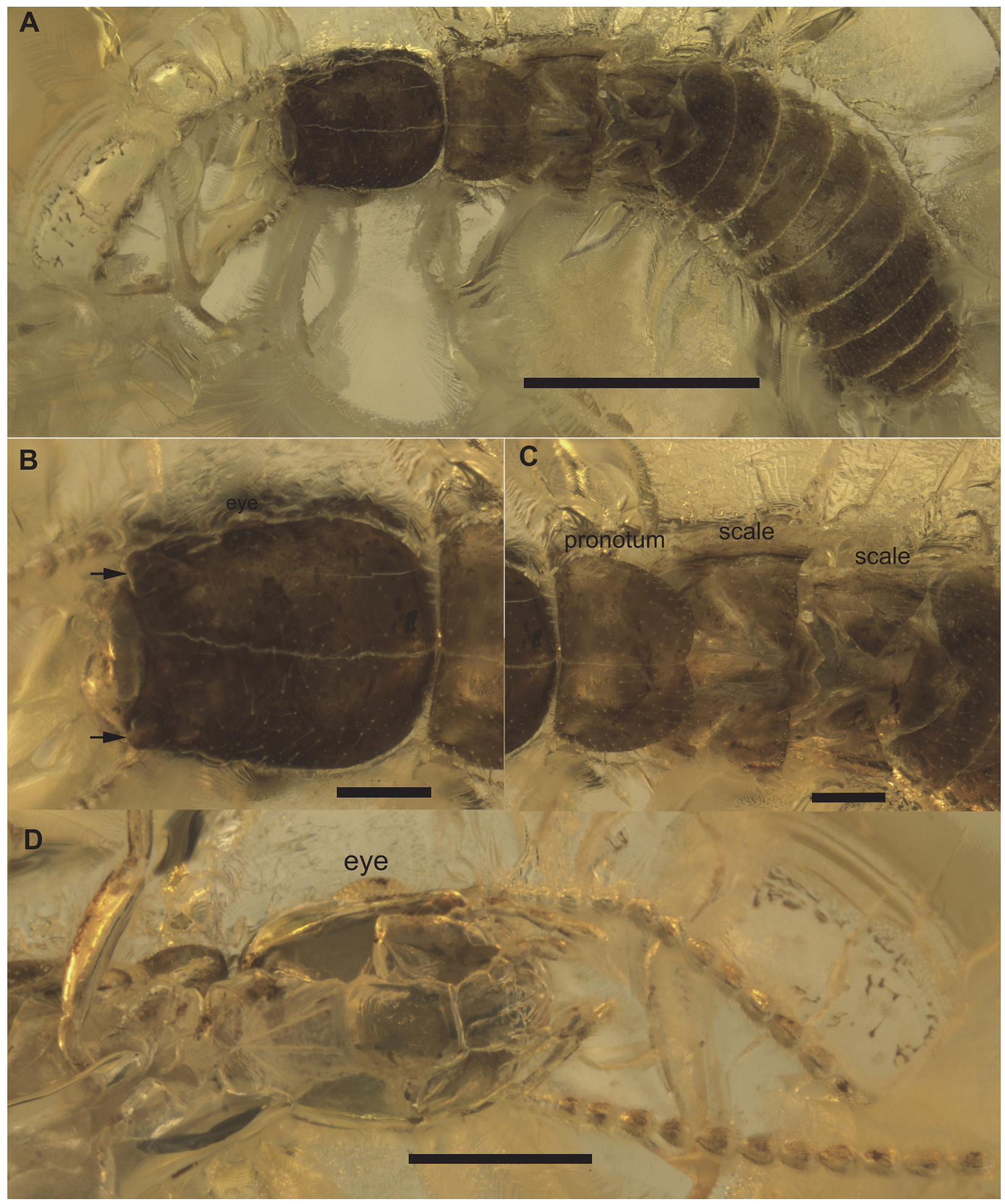

FIGURE 1. Lukotermes milescaput gen. et sp. nov., holotype L-122, female. General habitus (A), head from above, arrows: bumps (B), thorax from above (C), head from below (D). Scale bars equal $1 \mathrm{~mm}$ in A, $0.2 \mathrm{~mm}$ in B-C, $0.5 \mathrm{~mm}$ in $\mathbf{D}$. 


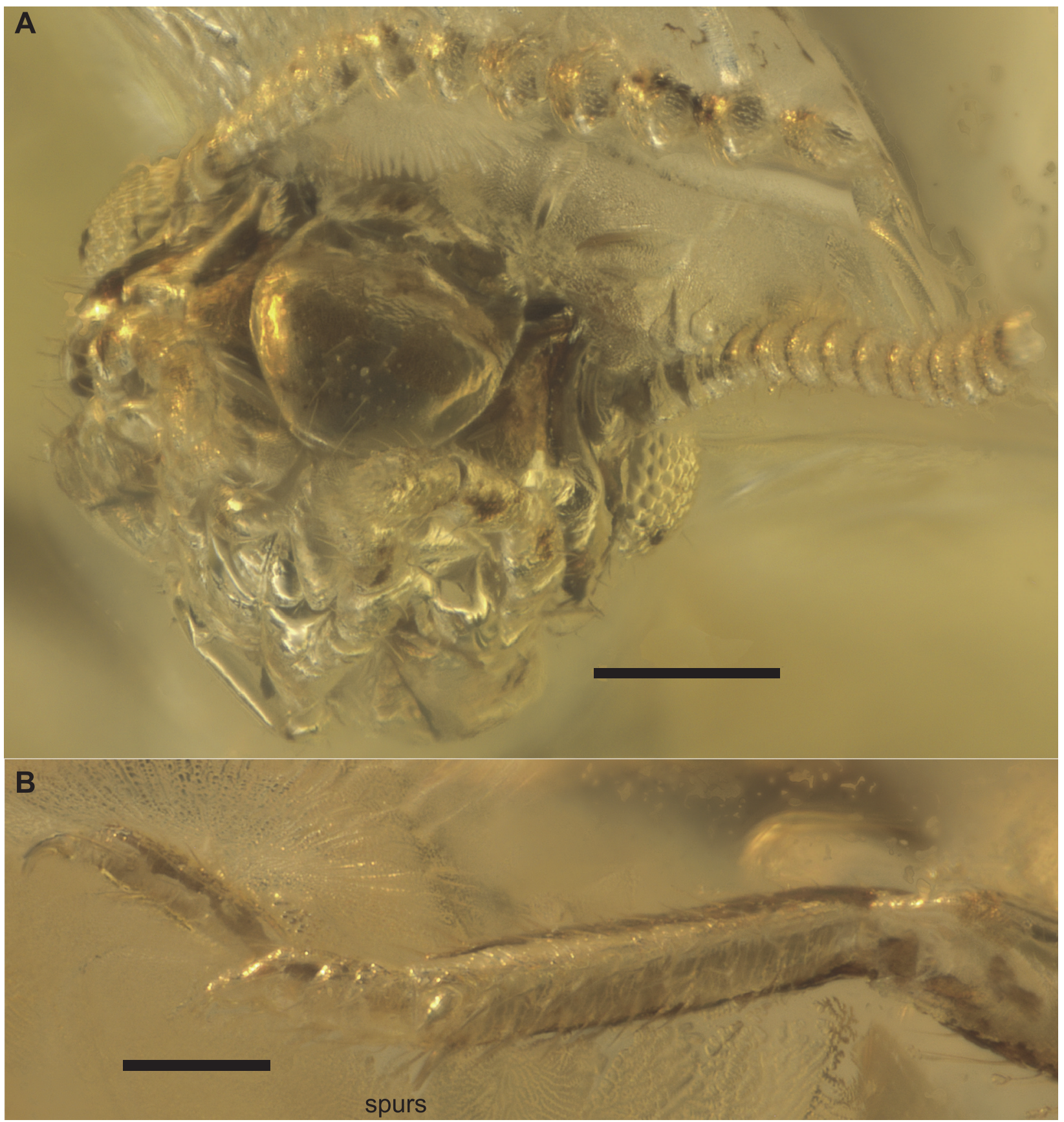

FIGURE 2. Lukotermes milescaput gen. et sp. nov., holotype L-122, female. Head frontal view (A), fore leg (B). Scale bars equal to $0.2 \mathrm{~mm}$ in $\mathbf{A}, 0.1 \mathrm{~mm}$ in $\mathbf{B}$.

mes Engel (in Engel et al., 2011), currently attributed to the rhinotermitid subfamily Prorhinotermitinae Quennedey and Deligne, 1975, have a tibial spur formula 2:2:2. Maiti (2006: 149) indicated that the unique extant prorhinotermitine genus Prorhinotermes Silvestri, 1909 has a spur formula 3:2:2, but Krishna and Grimaldi (2003: 3) supposed that it is 2:2:2; while it is 3:2:2 for Engel et al. (2011: 114, 120). Silvestri (1909: 287, figures
$49,61,63$ ) indicated 'Tibiae primi paris (figure 49) spinis tribus apicalibus, secundi et tertii paris spinis duabus armatae' and figured three spurs for the fore tibia of alate, soldier and worker. Thus 3:2:2 seems to be the correct issue for Prorhinotermes. Engel et al. (2011: 120) added that 'the distribution of the 3-2-2 tibial spur formula across Rhinotermitidae, and even Neoisoptera as a whole, suggests that it is a plesiomorphic condition for these sub- 


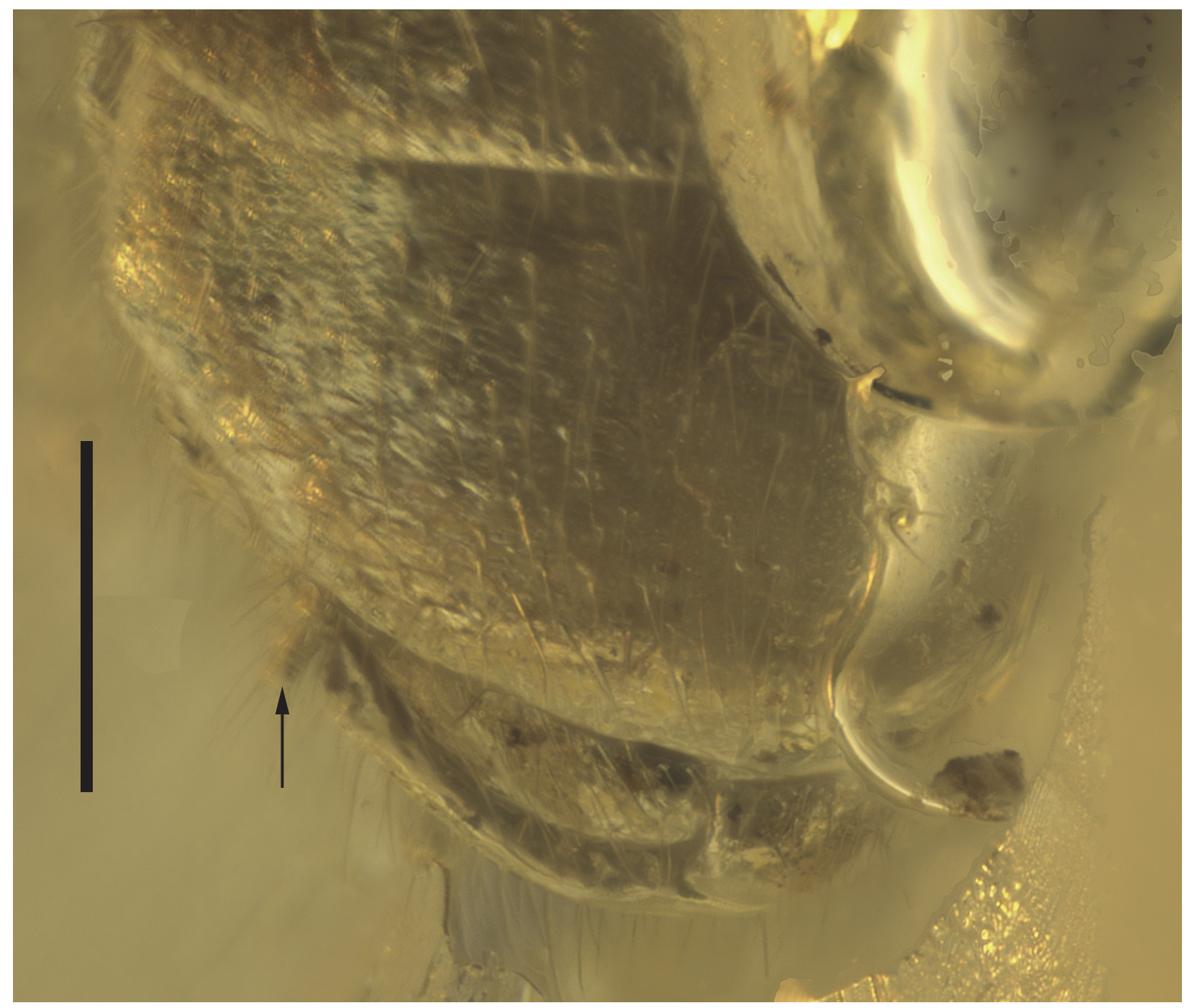

FIGURE 3. Lukotermes milescaput gen. et sp. nov., holotype L-122, female. Abdomen apex, arrow: cercus. Scale bar equals $0.2 \mathrm{~mm}$.

families, in which case the 2-2-2 tibial formula in Zophotermes is apomorphic'. Engel et al. (2011) did not discuss the possible affinities of Zophotermes with the Serritermitidae, but indicated (page 120) that Zophotermes 'shares with Prorhinotermitinae and Psammotermitinae the unique branching of the forewing $\mathrm{M}$ from CuA outside of the scale (figure 5), otherwise unknown among the Rhinotermitidae', that is M and CuA are basally coalescent and separate just distal of the scale. In Lukotermes gen. nov., M and CuA seem to be separated in the scale. In Glossotermes, M and CuA are currently supposed to be coalescent (Cancello and De Souza, 2005: 10, figure 12), while in Serritermes, $M$ is basally fused with $R$ (Emerson and Krishna, 1975: 6, figure 3). Thus the venation characters are homoplastic and not really sufficient for a family attribution.

It remains that the tibial spur formula $2: 2: 2$ is likely a specialized character convergently acquired and possibly related to the small sizes of the concerned taxa (viz. Glossotermes, Zophotermes and Lukotermes gen. nov.).

\section{Comparison with Glossotermes and Serritermes}

The head capsules of the imagoes of Glossotermes are rounded, strongly different from that of Lukotermes gen. nov. that is elongate, much longer than wide (Cancello and De Souza, 2005: figure 10). Also the pronotum of Glossotermes is narrower than head and with posterior margin slightly emarginate, while Lukotermes gen. nov. has a pro- 
notum as broad as head with posterior margin strongly emarginate. The head capsule of Serritermes is slightly broader than long (Emerson and Krishna, 1975: figure 1). If its pronotum is as broad as head in its anterior margin, its shape is quite different from that of Lukotermes gen. nov. in the sides more converging and posterior width along a line passing at median notch that is only $1 / 3$ the width along anterior margin (2/3 in Lukotermes gen. nov.). Lastly Serritermes has 13-14 antennomeres, instead of 15 in Lukotermes gen. nov., but the number of antennomeres can vary among different specimen of the same termite species.

\section{Comparison with the Subfamilies of Rhinotermitidae}

Apart for the tibial spur formula of Lukotermes gen. nov. that is only shared by Termitogeton and Zophotermes in the Rhinotermitidae, we compare our new genus with the different subfamilies. Krishna et al. (2013: 70) separated the Psammotermitinae Holmgren, 1911 from the other representatives of the Rhinotermitidae by the following character: 'forewing scale about same size as hind wing scale, not overlapping hind wing scale' (Psammotermitinae) vs. 'forewing scale distinctly overlapping hind wing scale, almost reaching tip of hind wing scale' (other taxa). These characters are clearly erroneous or badly expressed because in Reticulitermes, the forewing scales do not reach the tip of the hind wing scales (see Goellner, 1931: figure 1). Maiti (2006: 2) indicated that the 'forewing scale [is] generally large, overlapping the hind wing scale [in the Rhinotermitidae] except in Reticulitermes and Psammotermes'. The same author (page 14) proposed a different couplet, viz. 'forewing scale not longer than of hind wing scale' (Psammotermitinae) vs. 'forewing scale always longer than of hind wing scale' (other taxa). In Lukotermes gen. nov., the forewing scale is clearly longer than the hind wing one and slightly overlaps its base but not its apex. This character excludes the Psammotermitinae. Also the head shape of Lukotermes gen. nov. is different from that of Psammotermes Desneux, 1902 (see Maiti, 2006: figure 3 ), with parallel lateral sides and the head capsule longer than wide.

The postclypeus without a nose-like projection excludes affinities with the Rhinotermitinae (Maiti, 2006: figure 144B; Krishna et al., 2013). The Archeorhinotermitinae have the forewing scale overlapping the hind wing one, unlike Lukotermes gen. nov. (Krishna and Grimaldi, 2003). The heads of the alate Termitogetoninae (Termitogeton) are quite different from that of Lukotermes gen. nov., viz. subtriangular, broader than long, with a capsule distinctly narrower at level of eyes than in posterior part (Bugnion, 1914; Krishna and Grimaldi, 2003; Šobotník et al., 2010: figure 1A; Parmentier and Roisin, 2013: figure 3; Krishna et al., 2013). The Coptotermitinae Holmgren, 1910 and the extant Prorhinotermitinae have wide head capsules with rounded sides (Krishna and Grimaldi, 2003; Maiti, 2006; Krishna et al., 2013). Zophotermes has the forewing with scale overlapping hind wing scale, unlike in Lukotermes gen. nov.

A head with parallel sides, present in Lukotermes gen. nov., would characterize the Heterotermitinae (Krishna and Grimaldi, 2003; Krishna et al., 2013). But recent molecular phylogenetic analyses strongly suggest that the Heterotermitinae is paraphyletic to the Coptotermitinae, even with different topologies (Legendre et al., 2015; Dedeine et al., 2016; Bourguignon et al., 2016; Carrijo et al., 2020). Also, Engel et al. (2011: 113) indicated that Zophotermes has a 'Head not flattened, narrow oval in shape, with sides somewhat parallel (appears similar to condition in Heterotermitinae but there is some compression which may be obscuring slightly roundish borders)'. Thus the presence of parallel to subparallel sides of head is probably subject to homoplasy. Lukotermes gen. nov. also shares with the Heterotermitinae the barely visible ocelli. Reticulitermes is separated from Heterotermes Froggatt, 1896 after the shape of the labrum of the soldier, tongue-shaped in the former and needle-shaped labrum in the later, and after the structure of the mandible teeth in the alate. Both structures are unknown in Lukotermes gen. nov. Nevertheless, Lukotermes gen. nov. differs from Heterotermes in the presence of pronounced bump above the base of the antenna and the smaller compound eye (Watson et al., 1989: figures 17-19; Maiti, 2006: figures 57A, 60A, 64A, 67A, 70A, 75A, 77A, 78A, etc.), rather similar to that of Prorhinotermes (Krishna and Grimaldi, 2003). A similar bump is present in some Reticulitermes but clearly less pronounced than in Lukotermes gen. nov.; also, in both Reticulitermes and Heterotermes, the lateral sides of head capsules are less parallel and shorter in parts between the eyes and the postclypeus, than in Lukotermes gen. nov. (Goellner, 1931: figures 1, 3; Lash, 1952: figures 1-4; Hsia and Fan, 1965; Tsai et al., 1977, 1980; Ping et al., 1982; Ping, 1985; Takematsu, 1990: fig. 1, 1999: figures 1-4; Clément et al., 2001: figure 1; Lim and Forschler, 2012: figure 3; Ghesini and Marini, 2012: figure 2 A-B). The 
shape of the head capsule of Lukotermes gen. nov. is more similar to that of a soldier than to an alate in these genera. Reticulitermes flavipes (Kollar, 1837) would have also an elongate head capsule, but with the eyes situated closer to the bases of antennae than in Lukotermes gen. nov.

The Eocene Baltic amber Heterotermes eocenicus Engel, 2008 has much longer setae on head than in Lukotermes gen. nov., and its head capsule is rounded, apparently without bumps above the bases of the antennae (Engel, 2008). The head of the Miocene Mexican amber Heterotermes primaevus Snyder, 1960 is deformed and hardly comparable to that of Lukotermes gen. nov. (Snyder, 1960; Emerson, 1971). Its redescription, based on better preserved specimens, would be welcome. Numerous Cenozoic fossils are currently attributed to the genus Reticulitermes (Nel and Paicheler, 1993; Engel, 2008). Lukotermes gen. nov. differs from Reticulitermes antiquus in the 15 antennomeres, unlike 17-20 (Germar, 1813). Reticulitermes minimus Snyder, 1928 has 14 antennomeres, head and pronotum sizes compatible with those of Lukotermes gen. nov., anterior margin of pronotum straight, but an entire body length $6.15 \mathrm{~mm}$ contra $3.31 \mathrm{~mm}$ in Lukotermes gen. nov., and a forewing scale $0.5 \mathrm{~mm}$ long contra $0.43 \mathrm{~mm}$ in Lukotermes gen. nov. (Snyder, 1928; Engel et al., 2007; Engel, 2008). Reticulitermes minimus is poorly defined and needs to be revised.

\section{Miniaturization in Lukotermes gen. nov.}

The alate of Lukotermes gen. nov. is very small with a head capsule $0.80 \mathrm{~mm}$ long, $0.70 \mathrm{~mm}$ wide. These dimensions are comparable to those of Archeorhinotermes rossi Krishna and Grimaldi, 2003 (respectively, $0.77 \mathrm{~mm}$ and $0.69 \mathrm{~mm}$ ) slightly smaller than those of the smallest head of alates of Heterotermes and Reticulitermes (Goellner, 1931; Maiti, 2006). Termitogeton has head length to apex of the clypeus mostly larger than Lukotermes gen. nov. (Šobotník et al., 2010; Bourguignon and Roisin, 2011). The alate of the Eocene termitid genus Nanotermes Engel and Grimaldi (in Engel et al., 2011) has head length to apex of the clypeus 0.30 $\mathrm{mm}$ long, making it the smallest termite. Also, the forewing scale of Lukotermes gen. nov. is $0.43 \mathrm{~mm}$ long, three times as long as that of Nanotermes $(0.15 \mathrm{~mm}$ long for a wing length $2.60 \mathrm{~mm}$ ), but quite smaller than that of Archeorhinotermes rossi (0.64 mm long, for a wing length $4.40 \mathrm{~mm}$ ). Lukotermes gen. nov. had probably short wings but their exact lengths cannot be determined because the ratio (wing length/scale length) greatly varies among these termites.

Interestingly, Nanotermes has also a tibial spur formula 2:2:2, suggesting that this character could be linked to the miniaturization and/or juvenilisation. Indeed, e.g., Termitogeton has also antennae generally with 9 to 15 articles and wings without median and radial vein (Bourguignon and Roisin, 2011 and references therein). It seems that this character is subject to many convergences among the termites, as it is also present in some taxa of the termitid subfamilies Apicotermitinae, Termitinae, and Syntermitinae.

\section{CONCLUSION}

Because of the lack of information on its mandibles, the position of Lukotermes gen. nov. between the Rhinotermitidae vs. the Serritermitidae remains problematic. An attribution to the later family is possible because of the spur formula $2: 2: 2$. Nevertheless its shape of head and pronotum is very different from those of the extant Serritermitidae. It can be attributed to the Rhinotermitidae, possibly to the Heterotermitinae, on the basis of the elongate head with parallel lateral sides (but this character is somewhat subject to homoplasy as also present in Zophotermes). It does not fit in any of the extant and extinct rhinotermitid genera, and neither corresponds to any of the described Baltic amber Rhinotermitidae. Thus we consider that it corresponds to a new genus and species mainly characterized by an elongate head with lateral margins parallel and a strong bump above the antenna base. We provisionally attribute it to the Heterotermitinae. The discovery of a new alate with the mouthparts and wings better preserved would be welcome to precise its position.

The very particular shape of its head, looking more to a soldier head than to an alate one is surprising (compare with Maiti, 2006: figures 26, 30, 57 , etc.), although there are other similar cases, viz. we are currently describing another alate Mastotermitidae from the Cretaceous Crato Formation in Brazil that also shows an elongate head with lateral side strongly parallel similar to that of a soldier (Jouault et al., unpublished data).

All known Ypresian and the single Cretaceous Neoisoptera Archeorhinotermes rossi are small (Perkovsky and Vasilenko, 2020); it could reflect a unidirectional decrease in size as a general pattern of termite evolution (Nalepa, 2011). However, as the mating pair still requires a bare minimum of initial metabolic resources to initiate efficient colony foundation and provide biparental care, the com- 
bined initial weight of female and male explained $27 \%$ of the variation in incipient colony growth (Chouvenc, 2019 and references therein). Study of Chouvenc (2019) was done on a tropical rhinotermitid species introduced to Florida; probably that outside of tropics the initial weight of parents was even more important. It could the reason why miniaturization was much less expressed in Baltic and Rovno Priabonian amber forest with mesothermal climates with low seasonality and even in Ypresian Oise amber forest with paratropical climate, than in Ypresian Cambay tropical forest (Perkovsky and Vasilenko, 2020). The climate of Rovno amber forest was distinctly warmer than the Baltic one, and it can be the reason of Lukotermes absence in the huge amount of Baltic amber inclusions.

Emerson (1971: 257) suggested that 'probably the Termitidae replaced many genera of the Rhinotermitidae in similar habitats in ancient times, as they tend to do at present.' As we do not know any Asian or European descendants of Nanotermes, it seems that the first termitid attempts to distribute outside of Africa were 'unsuccessful' (Perkovsky and Vasilenko, 2020 and references therein); at least Nanotermes-size temites were too small not only for ecological domination, but even for long-term survival. Earlier African termitids should be much more diverse than first travelers outside of Africa, and their early descendants could have been larger than Nanotermes, preventing them from rapid extinction. As there was no termitid 'pressure' on rhinotermitids and stylotermitids (Perkovsky and Vasilenko, 2020), both families were much more diverse during the Eocene outside of Africa.

Lukotermes as part of this diversity can be especially interesting. It is not only very small for rhinotermitids, it has the smallest forewing scale in Rhinotermitidae and the second smallest forewing scale in fossil termites after Nanotermes. In extant Rhinotermitidae, small forewing scale is known only in Psammotermes, but this character is found in all Termitidae. We suppose that the characters of Lukotermes demonstrate an extreme miniaturization, possible for 'lower' termites without loss of their protist symbionts (see details in Perkovsky and Vasilenko, 2020). As in the recent molecular phylogenetic analyses (e.g., Bucek et al., 2019), the clade (Heterotemitinae + Coptotermitinae) forms the sister group of Termitidae, and as extreme miniaturization was an important step in termitid way to their extant ecological domination (Perkovsky and Vasilenko, 2020), the study of Lukotermes and its fossil relatives could be instrumental in the better understanding of higher termites' origin.

\section{ACKNOWLEDGMENTS}

We sincerely thank two anonymous referees for the useful comments on the first version of the paper. We are grateful to N.R. Khomich (Rovno) for help with acquiring the paratype, A.P. Vlaskin (SIZK) for cutting and primary polishing of the samples, S.A. Simutnik (SIZK) for photos, A.P. Rasnitsyn (Paleontological Institute, Moscow) for discussion.

\section{REFERENCES}

Bourguignon, T. and Roisin, Y. 2011. Revision of the termite family Rhinotermitidae (Isoptera) in New Guinea. In Engel, M.S. (ed.), Contributions Celebrating Kumar Krishna. ZooKeys, 148:55-103. https://doi.org/10.3897/zookeys.148.1826

Bourguignon, T., Lo, N., Šobotník, J., Sillam-Dussès, D., Roisin, Y., and Evans, T.A. 2016. Oceanic dispersal, vicariance and human introduction shaped the modern distribution of the termites Reticulitermes, Heterotermes, and Coptotermes. Proceedings of the Royal Society (B), 283(20160179):1-9. https://doi.org/10.1098/rspb.2016.0179

Brullé, G.A. 1832. Expédition scientifique de Morée. Section des sciences physiques zoologie. Deuxième section - des animaux articulés. Volume 3, Part 1. F.G. Levrault, Paris.

Brunner von Wattenwyl, C. 1882. Prodromus der europäischen Orthopteren. Verlag von Wilhelm Engelmann, Leipzig.

Bucek, A., Šobotník, J., He, S.-I., Shi, M., McMahon, D.P., Holmes, E.C., Roisin, Y., Lo, N., and Bourguignon, T. 2019. Evolution of termite symbiosis informed by transcriptome-based phylogenies. Current Biology, 29:3728-3734. https://doi.org/10.1016/j.cub.2019.08.076

Bugnion, E. 1914. Le Termitogeton umbiculatus Hag. (de Ceylan) (Corrodentia, Termitidae). Annales de la Société Entomologique de France, 83:39-47. 
Cancello, E.M. and De Souza, O. 2005. A new species of Glossotermes (Isoptera): reappraisal of the generic status with transfer from the Rhinotermitidae to the Serritermitidae. Sociobiology, 45:31-51.

Carrijo, T.F., Pontes-Nogueira, M., Santos, R.G., Morales, A.C., Cancello, E.M., and Scheffrahn, R.H. 2020. New World Heterotermes (Isoptera, Rhinotermitidae): molecular phylogeny, biogeography and description of a new species. Systematic Entomology, 45:527-539. https://doi.org/10.1111/syen.12412

Chouvenc, T. 2019. The relative importance of queen and king initial weights in termite colony foundation success. Insectes Sociaux, 66:177-184. https://doi.org/10.1007/s00040-019-00690-3

Clément, J.-L., Bagnères, A.-G., Uva, P., Wilfert, L., Quintana, A., Reinhard, J., and Dronnet, S. 2001. Biosystematics of Reticulitermes termites in Europe: morphology, chemical and molecular data. Insectes Sociaux, 48:202-215. https://doi.org/10.1007/PL00001768

Dedeine, F., Dupont, S., Guyot, S., Matsuura, K., Wang, C., Habibpour, B., Bagnères, A.-G., Mantovani, B., and Luchetti, A. 2016. Historical biogeography of Reticulitermes termites (Isoptera: Rhinotermitidae) inferred from analyses of mitochondrial and nuclear loci. Molecular Phylogenetics and Evolution, 94B:778-790. https://doi.org/10.1016/j.ympev.2015.10.020

Desneux, J. 1902. Termites du Sahara algérien recueillis par M. le Professeur Lameere. Annales de la Société Entomologique de Belgique, 46:436-440.

Desneux, J. 1904. Remarques critiques sur la phylogénie et la division systématique des Termitidae (Réponse à M. Wasmann). Annales de la Société Entomologique de Belgique, 48:372-378.

Emerson, A.E. 1950. Five new genera of termites from South America and Madagascar (Isoptera, Rhinotermitidae, Termitidae). American Museum Novitates, 1444:1-15. http://hdl.handle.net/2246/4329

Emerson, A.E. 1971. Tertiary fossil species of the Rhinotermitidae (Isoptera), phylogeny of genera, and reciprocal phylogeny of associated Flagellata (Protozoa) and the Staphylinidae (Coleoptera). Bulletin of the American Museum of Natural History, 146:243-303. http://hdl.handle.net/2246/1093

Emerson, A.E., and Krishna, K. 1975. The termite family Serritermitidae (Isoptera). American Museum Novitates, 2570:1-31.

Engel, M.S., Grimaldi, D.A., and Krishna, K. 2007. A synopsis of Baltic amber termites (Isoptera). Stuttgarter Beiträge zur Naturkunde (B), 372:1-20.

Engel, M.S. 2008. Two new termites in Baltic amber (Isoptera). Journal of the Kansas Entomological Society, 81:194-203. https://doi.org/10.2317/JKES-0802.01.1

Engel, M.S., Grimaldi, D.A., Nascimbene, P.C., and Singh, H. 2011. The termites of Early Eocene Cambay amber, with the earliest record of the Termitidae (Isoptera). In Engel, M.S. (ed.), Contributions Celebrating Kumar Krishna. ZooKeys, 148:105-123. https://doi.org/10.3897/zookeys.148.1797

Fossilworks database 2020. Fossilworks, Gateway to the Paleobiology Database. http://fossilworks.org/, accessed 01/12/2020.

Froggatt, W.W. 1896. Australian Termitidae. Part 2. Proceedings of the Linnean Society of New South Wales, 21:510-552.

Germar, E.F. 1813. Insecten in Bernstein eingeschlossen, beschrieben aus dem academischen Mineralien-Cabinet zu Halle. Magazin der Entomologie, 1:11-18.

Ghesini, S. and Marini, M. 2012. Morphology and phylogeny of Reticulitermes sp. (Isoptera, Rhinotermitidae) from Cyprus. Bulletin of Entomological Research, 102:672-681. https://doi.org/10.1017/S0007485312000260

Goellner, E.J. 1931. A new species of termite, Reticulitermes arenicola, from the sand dunes of Indiana and Michigan, along the shores of Lake Michigan. Proceedings of the Entomological Society of Washington, 33:227-234.

Holmgren, N. 1910. Das System der Termiten. Zoologischer Anzeiger, 35:284-286.

Holmgren, N. 1913. Termitenstudien. 4. Versuch einer systematischen Monographie der Termiten der Orientalischen Region. Kungliga Svenska Vetenskapsakademiens Handlingar, $50: 1-276$.

Hsia, K.-L. and Fan, S.-T. 1965. Notes on the genus Reticulitermes Holmgren of China. Acta Entomologica Sinica, 14:360-382. 
Jałoszyński, P. and Perkovsky, E.E. 2016. Diversity of Scydmaeninae (Coleoptera:

Staphylinidae) in Upper Eocene Rovno amber. Zootaxa, 4157:1-85. https://doi.org/10.11646/zootaxa.4157.1.1

Jałoszyński, P. and Perkovsky, E.E. 2019. The Mastigitae genus †Baltostigus in Upper Eocene Rovno amber (Coleoptera: Staphylinidae: Scydmaeninae). Zootaxa, 4661:594-600. https://doi.org/10.11646/zootaxa.4661.3.12

Kollar, V. 1837. Naturgeschichte der schädlichen Insecten in Beziehung auf Landwirthschaft und Forstcultur. Ferdinand Ullrich, Vienna.

Krishna, K. and Grimaldi, D.A. 2003. The first Cretaceous Rhinotermitidae (Isoptera): a new species, genus, and subfamily in Burmese amber. American Museum Novitates, 3390:1-10. https://doi.org/10.1206/0003-0082(2003)390<0001:TFCRIA>2.0.CO;2

Krishna, K., Engel, M.S., Grimaldi, D.A., and Krishna, V. 2013. Treatise on the Isoptera of the world. Bulletin of the American Museum of Natural History, 377:1-2704.

Lash, J.W. 1952. A new species of Reticulitermes (Isoptera) from Jerusalem, Palestine. American Museum Novitates, 1575:1-7.

Legalov, A.A., Nazarenko, V.Yu., and Perkovsky, E.E. 2019. New weevils (Coleoptera: Curculionidae) from Rovno amber. Paleontological Journal, 53:1045-1059. https://doi.org/10.1134/S0031030119100101

Legendre, F., Nel, A., Svenson, G.J., Robillard, T., Pellens, R., and Grandcolas, P. 2015. Phylogeny of Dictyoptera: dating the origin of cockroaches, praying mantises and termites with molecular data and controlled fossil evidence. PLos ONE, 10(7):e0130127. https://doi.org/10.1371/journal.pone.0130127

Light, S.F. 1921. Notes on Philippine termites. 1. The Philippine Journal of Science (D), 18:243257.

Lim, S.Y. and Forschler, B.T. 2012. Reticulitermes nelsonae, a new species of subterranean termite (Rhinotermitidae) from the Southeastern United States. Insects, 3:62-90.

Lyubarsky, G.Yu., and Perkovsky, E.E. 2020a. Olibrolitus, new genus of shining flower beetles (Coleoptera, Cucujoidea, Phalacridae) from Baltic and Bitterfeld amber. Paleontological Journal, 54:143-148. https://doi.org/10.1134/s0031030120020070

Lyubarsky, G.Yu. and Perkovsky, E.E. 2020b. First Rovno amber species of the genus Telmatophilus (Coleoptera: Clavicornia: Cryptophagidae) from Veselukha floodplain. Invertebrate Zoology, 17:25-35. https://doi.org/10.15298/invertzool.17.1.03

Maiti, P.K. 2006. A taxonomic monograph on the world species of termites of the family Rhinotermitidae (Isoptera: Insecta). Memoirs of the Zoological Survey of India, 20:1-272.

Makarkin, V.N. and Perkovsky, E.E. 2020. A new species of Proneuronema (Neuroptera: Hemerobiidae) from late Eocene Rovno amber. Zootaxa, 4718:292-300. https://doi.org/10.11646/zootaxa.4718.2.11

Mamontov, Yu.S., Atwood, J.J., Perkovsky, E.E., and Ignatov, M.S. 2020. Hepatics from Rovno amber (Ukraine): Frullania pycnoclada and a new species, F. vanae. The Bryologist, 123:421-430. https://doi.org/10.1639/0007-2745-123.3.421

Martynova, K.V., Perkovsky, E.E., Olmi, M., and Vasilenko, D.V. 2019. New records of Upper Eocene chrysidoid wasps (Hymenoptera: Chrysidoidea) from basins of Styr and Stokhod rivers (Rovno Amber). Paleontological Journal, 53:998-1023. https://doi.org/10.1134/S0031030119100125

Nadein, K.S., Perkovsky, E.E., and Moseyko, A.G. 2016. New Late Eocene Chrysomelidae (Insecta: Coleoptera) from Baltic, Rovno and Danish ambers. Papers in Palaeontology, 2:117-137. https://doi.org/10.1002/spp2.1034

Nalepa, C.A. 2011. Body size and termite evolution. Evolutionary Biology, 38(3):243-257. https://doi.org/10.1007/s11692-011-9121-z

Nel, A. and Paicheler, J.-C. 1993. Les Isoptera fossiles (Insecta, Dictyoptera). Cahiers de Paléontologie CNRS (ed.) Paris:102-179.

Parmentier, D. and Roisin, Y. 2003. Caste morphology and development in Termitogeton nr. planus (Insecta, Isoptera, Rhinotermitidae). Journal of Morphology, 255:79-69. https://doi.org/10.1002/jmor.10047

Perkovsky, E.E. 2000. The first evidence for Eocene drywood termites (Isoptera: Kalotermitidae) from Rovno amber. Dopovidi Natsional'noyi Akademiyi nauk Ukrayini, 9:190-192.

Perkovsky, E.E., Zosimovich, V.Yu, and Vlaskin, A.P. 2010. Rovno amber, p. 116-136. In Penney, D. (ed.), Biodiversity of Fossils in Amber from the Major World Deposits. Siri Sciences Press, Manchester. 
Perkovsky, E.E., Rasnitsyn, A.P., Vlaskin, A.P., and Rasnitsyn, S.P. 2012. Contribution to the study of the structure of amber forest communities based on analysis of syninclusions in the Rovno Amber (Late Eocene of Ukraine). Paleontologicheskii Zhurnal, 2012(3):70-78. [In Russian; English translation: Paleontological Journal, 46:293-301] https://doi.org/10.1134/S0031030112030136

Perkovsky, E.E. 2016. Tropical and Holarctic ants in Late Eocene ambers. Vestnik Zoologii, 50:111-122. https://doi.org/10.1515/vzoo-2016-0014

Perkovsky, E.E. 2017. Rovno amber caddisflies (Insecta, Trichoptera) from different localities, with information about three new sites. Vestnik Zoologii, 51:15-22. https://doi.org/10.1515/vzoo-2017-0003

Perkovsky, E.E. 2018. Only half of Rovno amber hymenopteran fauna is common with Baltic amber. Vestnik Zoologii, 52:353-360. https://doi.org/10.2478/vzoo-2018-0037

Perkovsky, E.E. and Olmi, M. 2018. Discovery of the first pincer wasp (Hymenoptera, Dryinidae) from Rovno amber. Zootaxa, 4457:296-304. https://doi.org/10.11646/zootaxa.4457.2.5

Perkovsky, E.E. and Makarkin, V.N. 2019. A new species of Succinoraphidia Aspöck \& Aspöck, 2004 (Raphidioptera: Raphidiidae) from the late Eocene Rovno amber, with venation characteristics of the genus. Zootaxa, 4576:570-580.

https://doi.org/10.11646/zootaxa.4576.3.9

Perkovsky, E.E. and Makarkin, V.N. 2020. A new species of Sympherobius Banks (Neuroptera: Hemerobiidae) from the late Eocene Rovno amber. Palaeoentomology, 3:196-203. https://doi.org/10.11646/palaeoentomology.3.2.9

Perkovsky, E.E., Olmi, M., Vasilenko, D.V., Capradossi, L., and Guglielmino, A. 2020. First Bocchus Ashmead (Hymenoptera: Dryinidae) from Upper Eocene Rovno amber: $B$. schmalhauseni sp. nov. Zootaxa, 4819:544-556. https://doi.org/10.11646/zootaxa.4819.3.6

Perkovsky E.E. and Vasilenko D.V. 2020. Evolution of tropical termites in early Paleogene with description of a new species of Stylotermitidae (Isoptera) from Rovno amber (late Eocene of Ukraine). Invertebrate Zoology, 17:205-218.

Ping, Z.-M., Xu, Y.-L., and Li, S. 1982. Two new species of the genus Reticulitermes. Acta Zootaxonomica Sinica, 7:419-424.

Ping, Z.-M. 1985. Eight new species of the genus Coptotermes and Reticulitermes from Guandong Province, China. Entomotaxonomia, 7:317-328.

Quennedey, A. and Deligne, J. 1975. L'arme frontale des soldats de termites. 1. Rhinotermitidae. Insectes Sociaux, 22:243-267. https://doi.org/10.1007/BF02223076

Radchenko, A. and Perkovsky, E.E. 2018. First record of fossil ant species Eocenomyrma rugosostriata (Mayr) (Hymenoptera: Formicidae) from the Rovno amber. Russian Entomological Journal, 27:285-288. https://doi.org/10.15298/rusentj.27.3.08

Radchenko, A.G. and Khomich, M.R. 2020. Ants of the extinct genus Cataglyphoides Dlussky, 2008 (Hymenoptera: Formicidae: Formicinae) from the late Eocene European ambers. Invertebrate Zoology, 17:154-161. https://doi.org/10.15298/invertzool.17.2.05

Radchenko, A.G. and Perkovsky, E.E. 2020. New records of the fossil ant genus Prionomyrmex Mayr (Hymenoptera, Formicidae, Myrmeciinae) from Late Eocene European ambers. Paleontolological Journal, 54:617-626. https://doi.org/10.1134/S0031030120060088

Silvestri, F. 1909. Isoptera, pp. 279-314. In Michaelson, W. and Hartmeyer, R. (eds.), Die Fauna Sudwest-Australiens, Volumne 2(17). Fischer, Jena.

Simutnik, S.A. and Perkovski, E.E. 2020. Ektopicercus Simutnik gen. nov. (Hymenoptera, Chalcidoidea, Encyrtidae) from late Eocene Rovno amber. Palaeoentomology, 3:342-346. https://doi.org/10.11646/palaeoentomology.3.4.3

Simutnik, S.A., Perkovsky, E.E., and Vasilenko D.V. 2020. First record of Leptoomus janzeni Gibson (Hymenoptera, Chalcidoidea) from Rovno amber. Journal of Hymenoptera Research, 80:137-145.

Snyder, T.E. 1928. A new Reticulitermes from Baltic Sea amber. Journal of the Washington Academy of Sciences, 18:515-517. https://www.jstor.org/stable/24528302

Snyder, T.E. 1960. Fossil termites from Tertiary amber of Chiapas (Mexico). Journal of Paleontology, 34:493-494. https://www.jstor.org/stable/1300948

Šobotník, J., Bourguignon, T., Hanus, R., Sillam-Dussès, D., Pflegerová, J., Weyda, F., Kutalová, K., Vytisková, B., and Roisin, Y. 2010. Not only soldiers have weapons: evolution of the frontal gland in imagoes of the termite families Rhinotermitidae and Serritermitidae. PLoS ONE, 5:e15761. https://doi.org/10.1371/journal.pone.0015761 
Takematsu, Y. 1990. Discovery of the winged form of Reticulitermes miyatakei Morimoto. Esakia Special Issue, 1:4-1.

Takematsu, Y. 1999. The genus Reticulitermes (Isoptera, Rhinotermitidae) in Japan, with description of a new species. Entomological Science, 2:231-243.

Tsai, P.-H., Huang, F.-S., and Li, K.-S. 1977. Notes on the genus Reticulitermes (Isoptera) from China, with descriptions of new subgenera and new species. Acta Entomologica Sinica, 20:465-475.

Tsai, P.-H., Huang, F.-S., Peng, J.-W., and Tong, X.-W. 1980. New species of the genus Reticulitermes (Isoptera, Rhinotermitidae) from Hunan, China. Acta Entomologica Sinica, 23:298-302.

von Rosen, K. 1913. Die fossilen Termiten: Ein kurtze Zusammenfassung der bis jetzt bekannten Funde. 2nd International Entomological Congress, Oxford, Transactions, 2:318-335.

Wasmann, E. 1897. Termiten von Madagaskar und Ostafrika (Voeltzkow, Wissenschaftliche Ergebnisse der Reisen in Madagaskar und Ost-Afrika, 1889-1895). Abhandlungen der Senckenbergischen Naturforschenden Gesellschaft, 21:137-182.

Watson, J.A.L., Brown, W.V., Miller, L.R., Carter, F.L., and Lacey, M.J. 1989. Taxonomy of Heterotermes (Isoptera: Rhinotermitidae) in South-Eastern Australia: cuticular hydrocarbons of workers, and soldier and alate morphology. Systematic Entomology, 14:299-325. https://doi.org/10.1111/j.1365-3113.1989.tb00287.x

Westwood, J.O. 1840. An introduction to the modern classification of insects; founded on the natural habits and corresponding organisation of the different families. Volume 2. Longman, Orme, Brown, Green, and Longmans, London. 